\title{
lgG4-related disease: a novel, important but easily missed condition
}

\author{
${ }^{1} \mathrm{JS}$ Lees, ${ }^{2} \mathrm{~N}$ Church, ${ }^{3} \mathrm{~B}$ Langdale-Brown, ${ }^{3} \mathrm{C}$ Bellamy, ${ }^{4} \mathrm{P}$ Gibson, ${ }^{4} \mathrm{~S}$ Watson \\ ${ }^{1}$ Core Medical Trainee, Department of Renal Medicine; ${ }^{2}$ Consultant Gastroenterologist, Department of Gastroenterology; ${ }^{3}$ Consultant \\ Histopathologist, Department of Histopathology; ${ }^{4}$ Consultant Nephrologist, Department of Renal Medicine; Royal Infirmary of Edinburgh, UK
}

ABSTRACT Immunoglobulin G4-related disease (IgG4-RD) is a multisystem, fibroinflammatory condition unrecognised in medical science until the last decade. It is characterised by progressive scarring and dysfunction of affected organs and tissues including the pancreas, hepatobiliary tree, kidneys, salivary glands, retroperitoneum and lungs. The diagnosis is made with the presence of numerous lgG4 positive plasma cells within a histologically-distinct chronic inflammatory process; most patients also have elevated serum lgG4. Though early cases were all identified in Japan, subsequent reports clearly demonstrate that lgG4-RD exists worldwide. There are no data confirming the prevalence of IgG4-RD in the West but it is thought to be very rare. Limited awareness of the condition and its heterogeneous presentation frequently results in misdiagnosis. Prompt and correct diagnosis is critical, as a rapid reversal of even advanced disease is often seen with corticosteroid therapy. We present three cases that illustrate some of the typical features of this condition.

KEYWORDS IgG4, IgG4-RD, interstitial nephritis, autoimmune pancreatitis, corticosteroids, retroperitoneal fibrosis

DECLARATION OF INTERESTS No conflicts of interest declared.

\author{
Correspondence to $S$ Watson \\ Department of Renal Medicine \\ Royal Infirmary of Edinburgh \\ 5 I Little France Crescent \\ Edinburgh EHI6 4SA, UK
}

tel. +44 (0) I3I 242 I246 e-mail simon.watson@nhs.net

\section{CASE I}

A 67-year-old man presented with a progressive decline in kidney function; serum creatinine rose from $73 \mu \mathrm{mol}$ to $346 \mu \mathrm{mol}(\mathrm{n}=60-120 \mu \mathrm{mol})$ between 2010 and 2012 (Figure IA). Previous medical history included recent onset type 2 diabetes mellitus ( $\mathrm{HbAlc}<7 \%$ - diet controlled),kidney stones and colorectal adenocarcinoma, treated with an anterior resection complicated by pseudomembranous colitis. Physical examination demonstrated evidence of previous colorectal surgery but no other medical condition of note. The clinical features are summarised in Table IA.

A urine dipstick test showed protein++ and blood+++. The urinary albumin:creatinine ratio was $3.7 \mathrm{mg} / \mathrm{mmoL}$ $(n=0-2.5)$. Urinary Bence Jones protein, plasma electrophoresis, serum calcium and liver function test (LFTs) results were normal. Immunological investigations are summarised in Table IB.

An abdominal ultrasound scan (USS) showed a nonobstructive left renal calculus. A biopsy of the left kidney was performed; the histological findings were consistent with IgG4-RD associated nephropathy, with coincidental clinically-insignificant mesangial immunoglobulin A ( $\lg A)$ disease (Figure IA).' This diagnosis was supported by significantly elevated serum IgG4 with otherwise normal
IgG4 subclasses (Table IB). Given normal LFTs and no significant pancreatic symptoms, the diagnosis of diabetes was felt to be unrelated to lgG4-RD.

Prednisolone $40 \mathrm{mg}$ once daily $(0.5 \mathrm{mg} / \mathrm{kg} / \mathrm{day})$ was commenced and the serum creatinine fell from $408 \mu \mathrm{mol}$ to $25 \mathrm{I} \mathrm{mmol}$ within four weeks (Figure IA). Gradual steroid reduction in $5 \mathrm{mg}$ increments per fortnight began after eight weeks; dialysis was not required.

\section{CASE 2}

A 55-year-old man presented with malaise, dyspepsia, weight loss $(7 \mathrm{~kg})$, dry eyes, intermittent cramps and pruritus. Previous medical history included chronic sialadenitis of the right submandibular gland and two pulmonary emboli (the patient was on life-long warfarin). He took no other long-term medications. His blood pressure was $131 / 83 \mathrm{~mm} \mathrm{Hg}$. A full physical examination was unremarkable. Urinalysis showed traces of blood and protein; the urinary protein: creatinine ratio was $122 \mathrm{mg} / \mathrm{mmol}(\mathrm{n}=0-15)$. The serum creatinine was $716 \mu \mathrm{mol}$ (estimated glomerular filtration rate $\left.[e G F R]=7 \mathrm{~mL} / \mathrm{min} / 1.73 \mathrm{~m}^{2}\right)$. C-reactive protein was elevated at $22 \mathrm{~g} / \mathrm{L}(\mathrm{n}=0-5)$ and he was anaemic with a haemoglobin $(\mathrm{Hb})$ of $106 \mathrm{~g} / \mathrm{L}(\mathrm{n}=130$ 180); haematinics, LFTs, calcium, phosphate and albumin were all normal and neither serum paraproteins nor 
TABLE IA Summary of the clinical features seen in three cases presented

\begin{tabular}{|l|l|l|l|}
\hline \multicolumn{2}{|l|}{ Case I } & Case 2 & Case 3 \\
\hline Age & 67 & 55 & 70 \\
\hline Gender & M & M & F \\
\hline Clinical presentation & $\begin{array}{l}\text { Incidental abnormal renal } \\
\text { function }\end{array}$ & $\begin{array}{l}\text { Malaise, dyspepsia, weight } \\
\text { loss, dry eyes, intermittent } \\
\text { cramps and pruritus }\end{array}$ & $\begin{array}{l}\text { Steatorrhoea, dark urine } \\
\text { and pruritis }\end{array}$ \\
\hline Organ involvement & Kidney & Kidney, salivary gland & Pancreas, retro-peritoneum \\
\hline Serum levels of lgG4 $(0.039-0.86 \mathrm{~g} / \mathrm{L})$ & 3.78 & $>1.56$ & 8.85 \\
\hline Treatment & Prednisolone & Prednisolone, azathioprine & Prednisolone \\
\hline Length of follow-up & 10 months & 6 years & I7 months \\
\hline
\end{tabular}

TABLE IB Summary of the immunological tests performed in each of the three cases presented

\begin{tabular}{|c|c|c|c|c|}
\hline Immunological test & & Case I & Case 2 & Case 3 \\
\hline \multirow[t]{5}{*}{ Serum level of lgG4 } & Total $(6.0-16.0 \mathrm{~g} / \mathrm{L})$ & 13.5 & 23.6 & 23.6 \\
\hline & $\operatorname{lgGI}(3.82-9.28 \mathrm{~g} / \mathrm{L})$ & 7.58 & 13.4 & 10 \\
\hline & $\operatorname{lgG} 2(2.4 \mathrm{I}-7.00 \mathrm{~g} / \mathrm{L})$ & 4.27 & 6.43 & 2.49 \\
\hline & $\operatorname{lgG} 3(0.22-1.76 \mathrm{~g} / \mathrm{L})$ & 1.43 & $>1.99$ & 1.41 \\
\hline & $\operatorname{lgG} 4(0.039-0.86 \mathrm{~g} / \mathrm{L})$ & 3.78 & $>1.56$ & 8.85 \\
\hline \multirow[t]{2}{*}{ ANCA by EIA } & MPO & Negative & Negative & Not tested \\
\hline & PR3 & Negative & Negative & Not tested \\
\hline ANA & & Negative & $\begin{array}{l}\text { Positive (1/40 } \\
\text { homogeneous) }\end{array}$ & $\begin{array}{l}\text { Positive ( } 1 / 160 \\
\text { homogeneous) }\end{array}$ \\
\hline Anti-dsDNA (0-15 IU/mL) & & Not tested & 39 & 27.1 \\
\hline \multirow[t]{6}{*}{ ENA screen } & Ro & Negative & Not tested & Not tested \\
\hline & $\mathrm{La}$ & Negative & Not tested & Not tested \\
\hline & $\mathrm{Sm}$ & Negative & Not tested & Not tested \\
\hline & RNP & Negative & Not tested & Not tested \\
\hline & SCI70 & Negative & Not tested & Not tested \\
\hline & Jol & Negative & Not tested & Not tested \\
\hline Anti-GBM (0-20 U/mL) & & Not tested & 4.5 & Not tested \\
\hline C3 (0.73-I.4 g/L) & & 0.88 & 0.43 & Not tested \\
\hline C4 (0.12-0.3 g/L) & & 0.1 & 0.02 & Not tested \\
\hline $\begin{array}{l}\text { Classical complement pathway (47.6- } \\
\text { I } 30.4 \% \text { activity) }\end{array}$ & & 0.6 & Not tested & Not tested \\
\hline Total haemolytic complement & & Not tested & No lysis & Not tested \\
\hline Anti thyroid peroxidase $(0-50 \mathrm{U} / \mathrm{mL})$ & & Not tested & Not tested & 17.0 \\
\hline Intrinsic factor $(0-6.0 \mathrm{IU} / \mathrm{mL})$ & & 0.4 & Not tested & Not tested \\
\hline Smooth muscle antibody & & Not tested & Not tested & Not tested \\
\hline Gastric parietal cell & & Not tested & Not tested & Positive \\
\hline Mitochondrial antibody & & Not tested & Not tested & Negative \\
\hline Cyclic citrullinated peptide $(0-4.8 \mathrm{U} / \mathrm{mL})$ & & 1.8 & Not tested & Not tested \\
\hline Rheumatoid factor $(0-20 \mathrm{IU} / \mathrm{mL})$ & & Not tested & 2 & Not tested \\
\hline \multicolumn{5}{|c|}{$\begin{array}{l}\text { ANCA by EIA= anti-neutrophil cytoplasmic antibody by enzyme immunoassay; ANA= anti-nuclear antibo } \\
\text { Anti-dsDNA= anti-double stranded dexoxyribonucleic acid antibody; ENA= extractable nuclear antigen; } \\
\text { MPO= myeloperoxidase; } \mathbf{P R 3}=\text { proteinase } 3 ; \mathbf{R N P}=\text { ribonuclear protein; } \mathbf{C} 3=\text { complement component } 3 ; \\
\text { C4= complement component } 4\end{array}$} \\
\hline
\end{tabular}



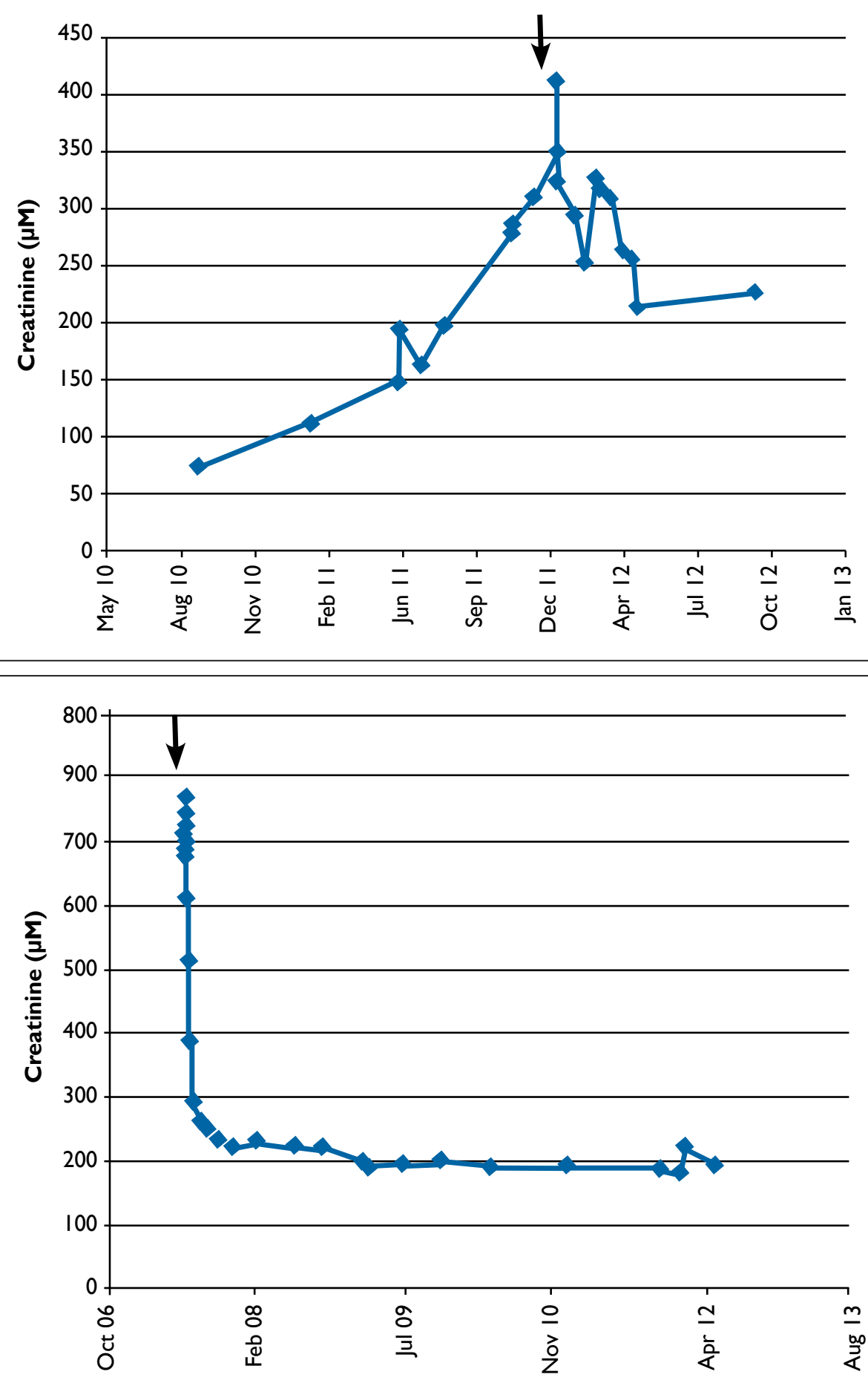

FIGURES IA AND IB Graphs showing serial serum creatinine measurements ( $\mu$ mol $Y$-axis) over time (year, $X$-axis) for case I (upper graph) and case 2 (lower graph). In each graph arrows indicate the time that corticosteroid therapy was commenced.

urinary Bence Jones protein were identified. Immunology is summarised in Table IB. Chest radiograph and a renal tract USS were unremarkable.

A renal biopsy showed significant fibrosis, plasma cell and eosinophil-rich interstitial nephritis consistent with IgG4-RD nephritis, supported by a raised serum IgG4 (Tables IA/IB). A retrospective analysis of previously- resected submandibular gland tissue also demonstrated lgG4-related disease. The patient's serum creatinine fell rapidly following the commencement of prednisolone 60 $\mathrm{mg} /$ day (7/6 to $386 \mu \mathrm{mol}$ within two weeks. Figure IB). Steroids were subsequently withdrawn and stable, moderate chronic kidney disease (CKD) was treated with $100 \mathrm{mg} /$ day of azathioprine. 


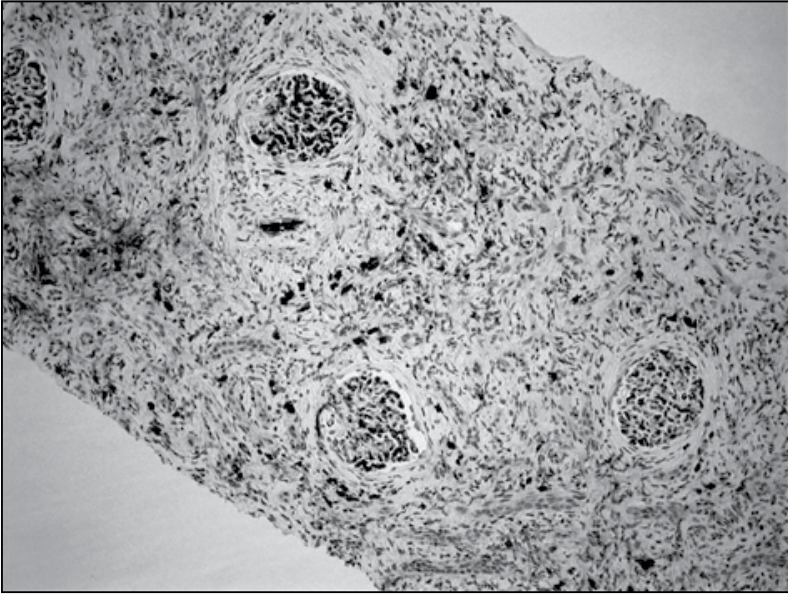

FIGURE IC Representative image of the renal biopsy from Case I demonstrating severe chronic tubulointerstitial nephritis, tubular atrophy, interstitial scarring, dense fibroblastic sclerosis and loss of peritubular capillaries. Numerous lgG4 positive plasma cells (dark staining) are seen in glomeruli and tubulointerstitial compartments. With immunofluorescence, glomeruli showed mild to moderate (++) mesangial granular immunopositivity for IgA and weak positivity for complement C3, but were immunonegative for other immunoglobulin heavy chains, complement $\mathrm{Clq}$ and light chains. On light microscopy there was no mesangial, endocapillary or extra capillary proliferation, no significant mesangial matrix increase and no evidence of segmental sclerosis or other attributable lesion. Electron microscopy showed mild expansion of mesangial matrix with some wrinkling of capillary walls but no electron dense deposits in the planes of section. It was concluded that the mesangial IgA identified was incidental to the clinical presentation, and not associated with metrics of significant glomerulonephritic activity or attributable lesions of chronic glomerulonephritis. Similar features (except IgA nephropathy) seen in the biopsy from Case 2.

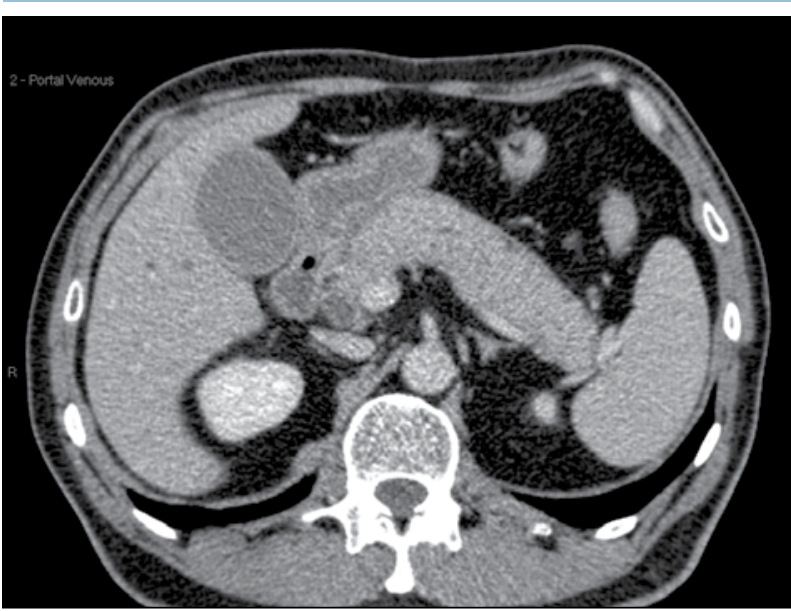

FIGURE 2A Representative imaging in IgG4-RD pancreatic/ biliary disease. Computed tomography scan of the abdomen demonstrating a 'sausage' pancreas with surrounding hypoechoic rim, classical features of IgG4-RD/autoimmune pancreatitis.

\section{CASE 3}

A 70-year-old woman presented with steatorrhoea, dark urine and pruritis. She maintained a good appetite and denied weight loss. Her past medical history included
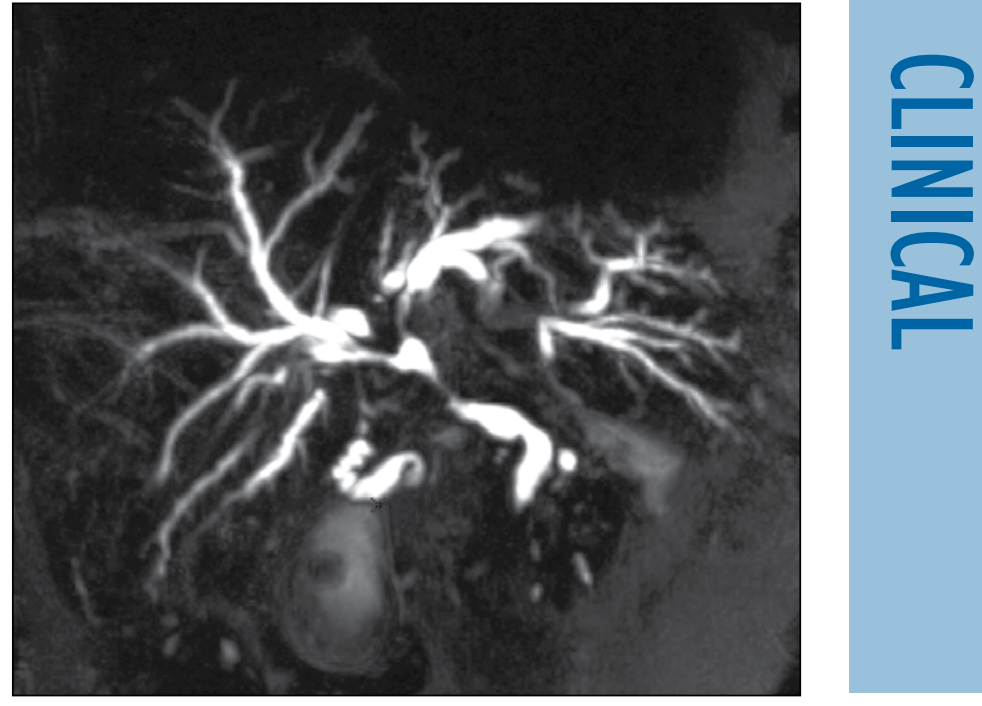

FIGURE 2B Magnetic resonance cholangio-pancreatography (MRCP) cholangiogram demonstrating multiple strictures throughout the biliary tree.

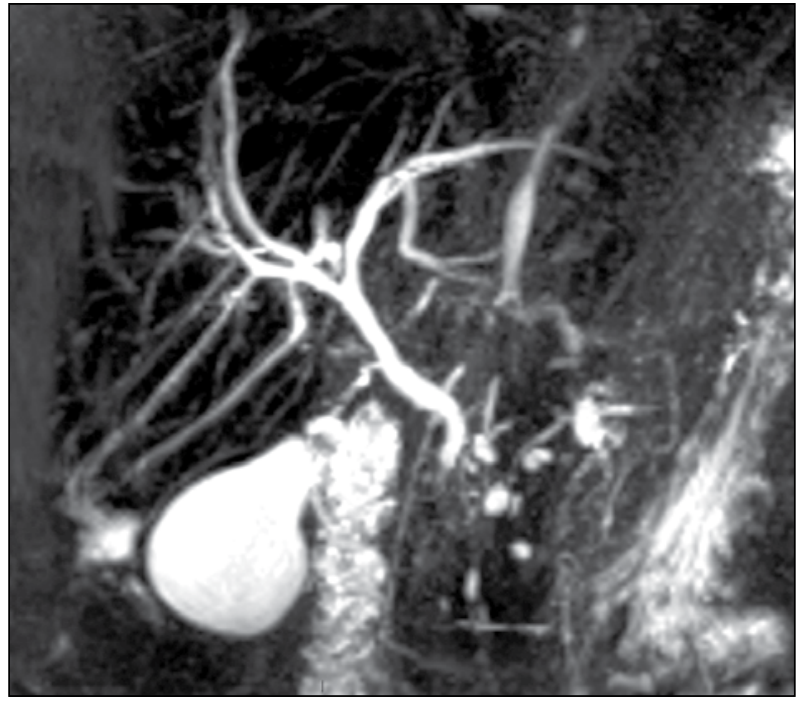

FIGURE 2C Resolution of the changes seen in previous Figure after four weeks of corticosteroid therapy.

asthma, gastroesophageal reflux disease and impaired glucose tolerance. Blood tests showed bilirubin $10 \mu \mathrm{mol}$ $(n=3-16)$, alanine-transferase (ALT) $63 \mathrm{U} / \mathrm{L}(n=10-50)$, alkaline phosphatase I,2I5 U/L $(n=40-125)$, gamma glutamyltranspeptidase (GGT) I58 U/L $(n=5-35)$ and evidence of renal impairment - serum creatinine 130 $\mu \mathrm{mol}(\mathrm{n}=60-120)$, eGFR 35 with normal electrolytes. She had normocytic anaemia (Hb $99 \mathrm{~g} / \mathrm{L}$ [n=II5-160 $\mathrm{g} / \mathrm{L}])$ with normal haematinics. Albumin was low at 33 $\mathrm{g} / \mathrm{L}(\mathrm{n}=35-50)$ and faecal elastase very low $(<50 \mu \mathrm{g} / \mathrm{g}$ $[n=200-1,000])$ suggesting pancreatic insufficiency. A coagulation screen, amylase, ferritin and serum calcium levels were normal. An abdominal USS revealed a distended gallbladder with calculi and debris, dilated intra- and extra-hepatic bile ducts and a possible mass at the pancreatic head. Computerised tomography (CT) scanning of the abdomen identified a bulky pancreatic 
head and uncinate process, gallstones and biliary dilatation with retroperitoneal fibrosis and cortical enhancement of two unobstructed kidneys. On endoscopic USS, appearances were strongly suggestive of an autoimmune pancreatitis (AIP) and magnetic resonance cholangiopancreatography (MRCP) demonstrated an atrophied pancreas with an irregular pancreatic duct and a common bile duct stricture (Figures 2A-C). A percutaneous pancreatic biopsy showed features consistent with AIP (Figures $3 \mathrm{~A}$ and B). Serum IgG4 was markedly elevated with normal or only mildly elevated lgGI-3 subtypes (Table IB). Prednisolone $40 \mathrm{mg} /$ day was commenced and LFTs rapidly improved (bilirubin $4 \mu \mathrm{moL} / \mathrm{L}, \mathrm{ALT} 27 \mathrm{U} / \mathrm{L}$, alkaline phosphatase $228 \mathrm{U} / \mathrm{L}$ and GGT $74 \mathrm{U} / \mathrm{L}$ ), together with radiological and clinical resolution of features of obstruction and pancreatic insufficiency.

TABLE 2 Common organs affected by lgG4-RD.A review by Zen and Nakanuma ${ }^{15}$ of 114 cases of IgG4-RD identified 206 separate histologically confirmed lesions. The distribution of these lesions and the frequency (expressed as a percentage of the total number of lesions) is summarised below.

\begin{tabular}{|l|c|}
\hline Anatomical site & $\begin{array}{c}\text { Frequency } \\
\text { (\% of total) }\end{array}$ \\
\hline Liver and biliary tree & 26 \\
\hline Salivary and lacrimal glands & 26 \\
\hline Lungs and pleura & 15 \\
\hline Pancreas & 14 \\
\hline Aortitis and retroperitoneal fibrosis & $\mathrm{II}$ \\
\hline Kidney & 5 \\
\hline $\begin{array}{l}\text { Other (lymph nodes, prostate, breast and } \\
\text { peripheral nerves }\end{array}$ & 4 \\
\hline
\end{tabular}

\section{DISCUSSION}

The cases we have presented demonstrate many typical clinical manifestations of lgG4-RD including AIP,' sialadenitis (Mikulicz's disease), ${ }^{2}$ parenchymal kidney disease ${ }^{3,4}$ and retroperitonal fibrosis. ${ }^{5.6} \mathrm{~A}$ comprehensive list of frequently affected organs is listed in Table 2. The diagnosis is based upon end-organ dysfunction due to a distinct form of chronic inflammation and elevation of serum lgG4 (>I.35 $\mathrm{g} / \mathrm{L})$. The characteristic histopathological features are a marked lymphoplasmacytic infiltration, storiform fibrosis, occlusive venulitis and increased lgG4+ plasma cells (Figures $3 C, D, E$ and F). In recent years, consensus diagnostic and management guidelines have been developed. ${ }^{7-9}$ There are several detailed reviews of this condition covering many clinical and biological aspects of lgG4-RD. ${ }^{10-17}$

Immunoglobulin G4-related disease causes significant morbidity due to direct organ damage and indirectly by misidentification as malignancy. The AIP mimicry of pancreatic cancer is particularly problematic and, historically, accounted for approximately a quarter of the cases of non-malignant pancreatic mass lesions removed using Whipple's procedure. ${ }^{18}$ The identification

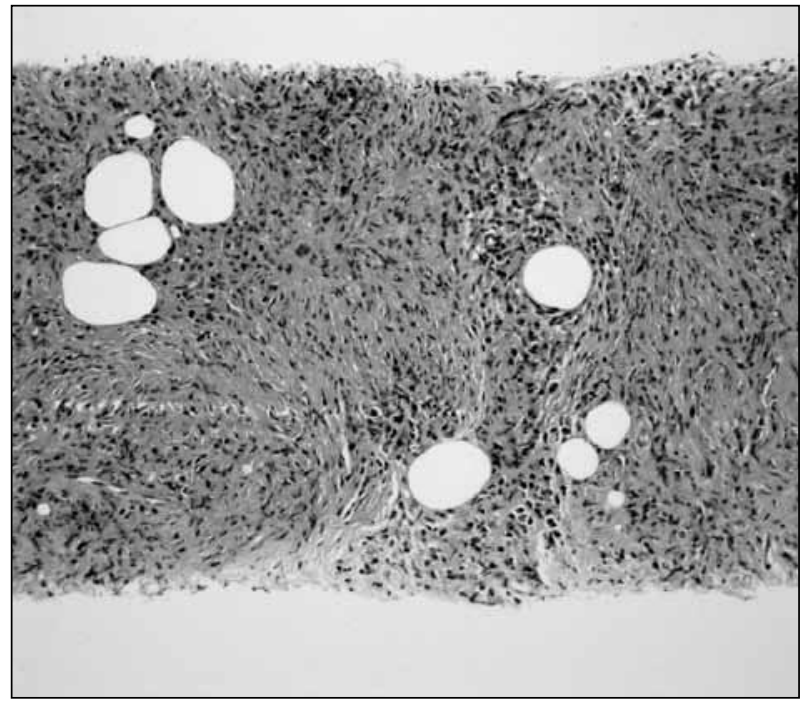

FIGURE 3A Haematoxylin and eosin stain (H\&E): Case 3 pancreatic trucut biopsy: representative image showing lymphoplasmacytic inflammation, fibrosis and virtually no recognisable pancreatic tissue.

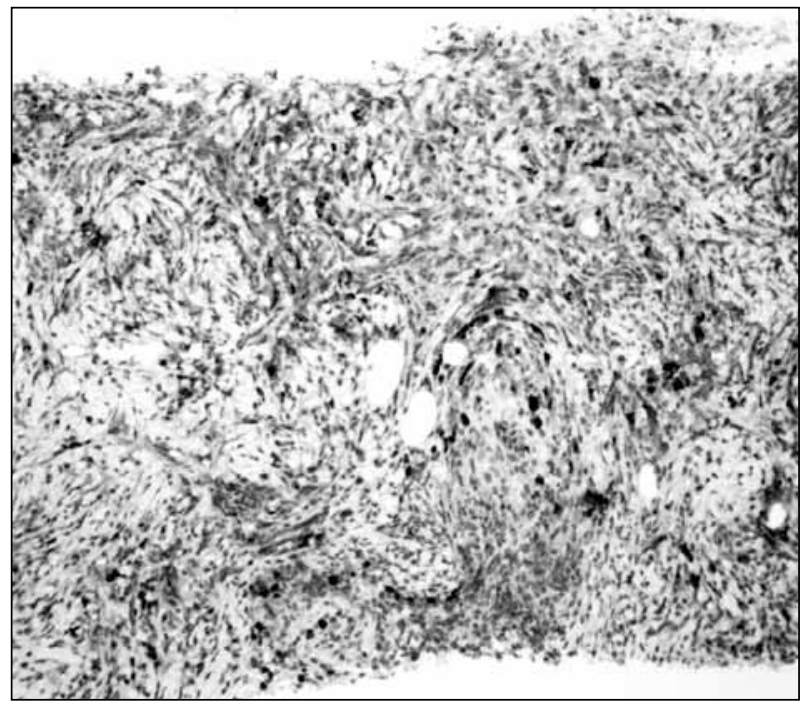

FIGURE 3B IgG4 stain: Case 3 pancreatic trucut biopsy: representative image showing increased numbers of lgG4 positive plasma cells (dark staining).

of serum $\lg G 4$ as a discriminating factor for $\lg G 4-R D$ has aided diagnosis, though raised lgG4 alone should not be relied upon; ${ }^{9,18-21}$ confirmatory tissue diagnosis is usually required.

The majority of reported cases of IgG4-RD are in Japanese patients, though it is unclear whether this reflects greater prevalence or better recognition of the condition in Japan..$^{22}$ However, it has become clear that IgG4-RD is neither confined to Japan nor patients of Japanese origin but affects patients around the world. ${ }^{3.23-29}$ Epidemiological data come largely from a single Japanese study of AIP which described a male:female ratio of 2.85: I, peak age of onset of $61-65$ years old and an estimated prevalence of 0.82 per 100,000 adults. $^{30}$ There is no 


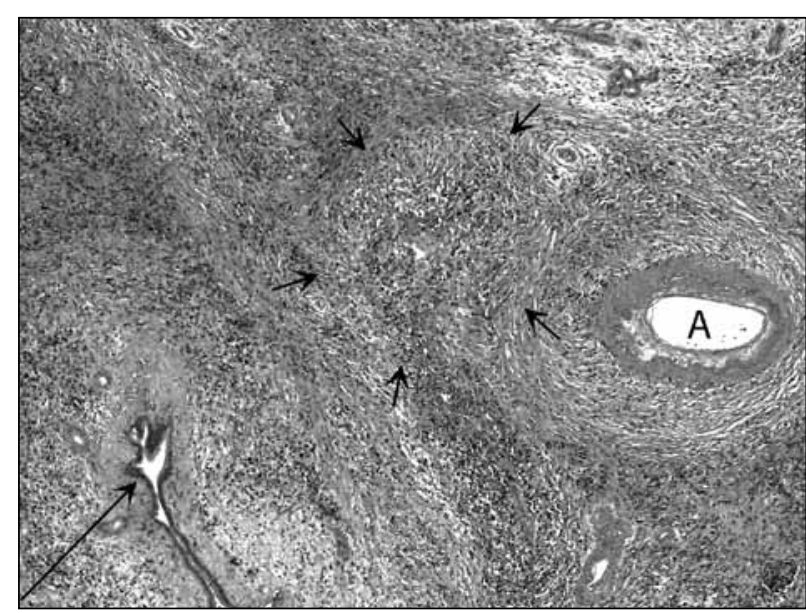

FIGURE 3C Haematoxylin and eosin stain (H\&E). A typical example of lgG4-related autoimmune pancreatitis in a Whipple's resection (from another patient). Virtually all of the normal pancreatic tissue has been replaced by a

lymphoplasmacytic infiltrate and storiform fibrosis. A residual pancreatic duct is seen bottom left (long arrow). An arteriole, (A), is seen on the right, but its accompanying venule (short arrows), is almost undetectable on H\&E due to the occlusive venulitis which is characteristic of IgG4-RD.

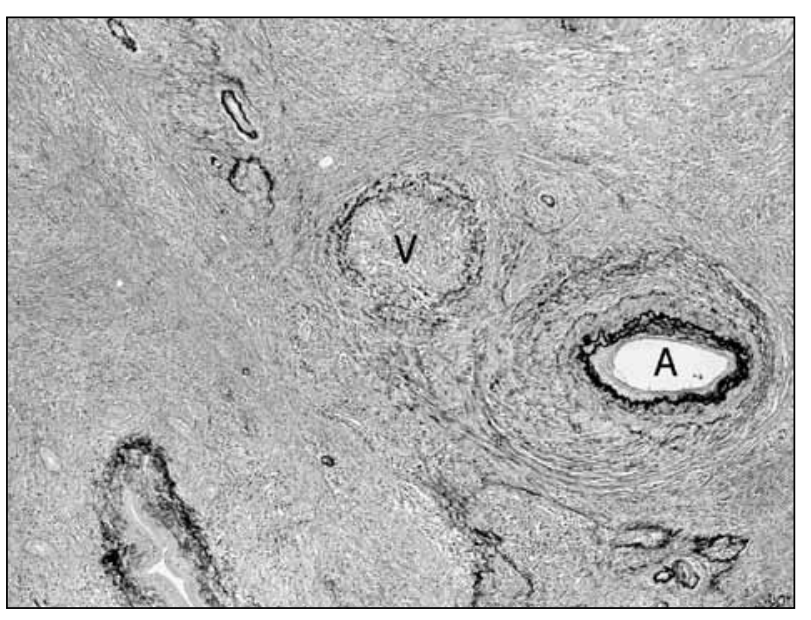

FIGURE 3D Same area as Figure 2C: this elastic van Gieson (EVG) stain highlights the occlusive venulitis. The venule $(\mathrm{V})$ is now easily detectable.

reliable estimate of prevalence in the West, however it can be seen in comparison with other better known conditions (the prevalence of Hodgkin's lymphoma and amyloid A [AA] amyloidosis in Western Europe for example are 0.5 and 1.0 per 100,000 respectively). ${ }^{31,32}$

The disease is a direct cause of significant damage to affected tissues ${ }^{3,33-36}$ but it is usually highly responsive to steroid therapy. ${ }^{37}$ Standard therapy is prednisolone 0.6 $\mathrm{mg} / \mathrm{kg}$ induction treatment for two to four weeks, reducing by $5 \mathrm{mg}$ increments every one to two weeks. ${ }^{38}$ The efficacy of corticosteroids in even advanced cases of IgG4-RD kidney disease is well-established and rapid response to steroid therapy can help to establish the diagnosis., ${ }^{3,27,39-43}$ Second-line immunosuppression using

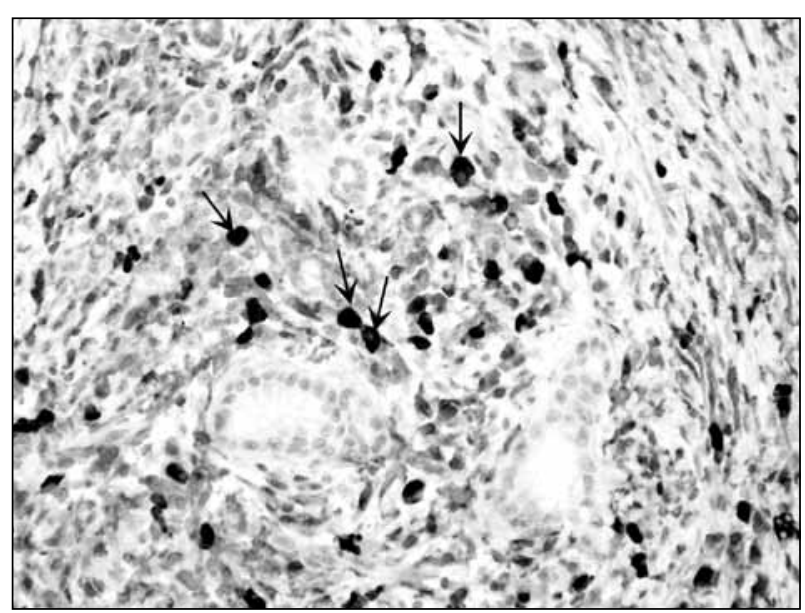

FIGURE 3E lgG4 stain. Same case as Figures 2C/2D: IgG4related autoimmune pancreatitis. Representative image showing 25 lgG4 positive plasma cells per high power field.

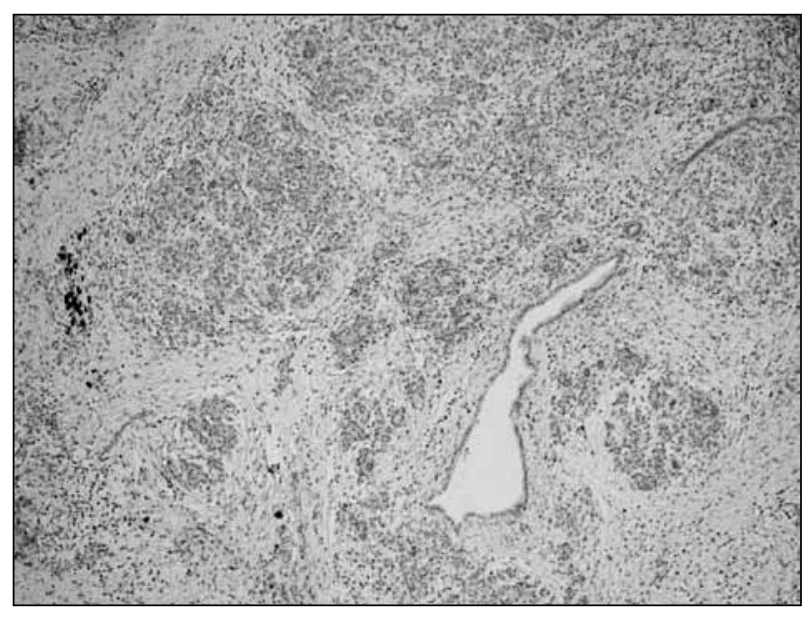

FIGURE 3F For comparison. Usual type chronic pancreatitis (not lgG4-related) stained with $\lg G 4$ - this representative low power view shows that in most areas there are no $\operatorname{lgG} 4$ positive plasma cells per high power field. A rare cluster of positive cells is seen on the left. The average count is less than one per high power field, range $0-13$.

\section{SUMMARY}

I. IgG4-RD is a multisystem disorder affecting many organs but with a preponderance for glandular tissues.

2. Older males are most often affected.

3. Serum IgG4 is a useful diagnostic marker but tissue or radiological evidence is usually required before treatment begins.

4. Corticosteroids are almost always the first-line therapy.

5. Even very advanced cases are frequently responsive to corticosteroid therapy. 
azathioprine, ${ }^{44}$ mycophenolate mofetil, ${ }^{45}$ bortezomib (a proteasome inhibitor with cytotoxic effect against plasma cells) ${ }^{46}$ and rituximab (a monoclonal antibody against the CD20 protein $)^{47,48}$ have been described.

We believe that clinicians in a wide variety of specialities are probably encountering, but perhaps not always identifying, cases of lgG4-RD. We acknowledge the

\section{REFERENCES}

I Sarles H, Sarles JC, Muratore R et al. Chronic inflammatory sclerosis of the pancreas - an autonomous pancreatic disease? Am J Dig Dis 196I; 6:688-98. http://dx.doi.org/I0.I007/BF0223234 I

2 Mikulicz J. Über eine eigenartige symmetrische Erkrankung der Tränen und Mundspeicheldrüsen. Beitr Chir Fortsch Gewidmet Theodor Billroth 1892;610-30. German.

3 Watson SJ, Jenkins DA, Bellamy CO. Nephropathy in IgG4-related systemic disease. Am J Surg Pathol 2006; 30:1472-7. http://dx.doi. org/I0.1097/0I.pas.00002I3308.43929.97

4 Takeda S, Haratake J, Kasai T et al. IgG4-associated idiopathic tubulointerstitial nephritis complicating autoimmune pancreatitis. Nephrol Dial Transplant 2004; 19:474-6. http://dx.doi.org//0.1093/ ndt/gfg477

5 Fukukura Y, Fujiyoshi F, Nakamura F et al.Autoimmune pancreatitis associated with idiopathic retroperitoneal fibrosis. AJR Am J Roentgenol 2003; I81:993-5.

6 Sevenet F, Capron-Chivrac D, Delcenserie R et al. Idiopathic retroperitoneal fibrosis and primary biliary cirrhosis. A new association? Arch Intern Med 1985; 145:2124-5. http://dx.doi. org/I0.100I/archinte.1985.00360II0200042

7 Massachusetts General Hospital. IgG4-related disease responder index (lgG4-RD Rl) [Internet]. Boston: MGH [cited 2013 Jan 24]. Available from: http://www2.massgeneral.org/pathology/symposium/pdf/ PDFI - Responder Index instruction guide.pdf.

8 Umehara H, Okazaki K, Masaki Y et al. Comprehensive diagnostic criteria for IgG4-related disease (IgG4-RD), 201 I. Mod Rheumatol 20I2; 22:2 I-30. http://dx.doi.org/ I0.1007/s I0 I65-0 I I-057 I-z

9 Shimosegawa T, Chari ST, Frulloni L et al. International consensus diagnostic criteria for autoimmune pancreatitis: guidelines of the International Association of Pancreatology. Pancreas 20I I; 40:3528. http://dx.doi.org//0.1097/MPA.0b0 I3e3182/42fd2

10 Stone JH, Zen Y, Deshpande V. IgG4-related disease. New Engl J Med 2012; 366:539-5I. http://dx.doi.org/ I0.I056/NEJMra I I 04650

II Khosroshahi A, Stone JH. A clinical overview of IgG-4 related systemic disease. Curr Opin Rheumatol 201 I; 23:57-66. http:// dx.doi.org//0.1097/BOR.0b0/3e32834/8057

12 Khosroshahi A, Stone JH. Treatment approaches to IgG-4 related systemic disease. Curr Opin Rheumatol 20II; 23:67-7I. http:// dx.doi.org/I0.I097/BOR.0b0 I 3e32834 Ia240

I3 Khosroshahi A, Stone JH. IgG4-related systemic disease: the age of discovery. Curr Opin Rheumatol 20II; 23:72-3. http://dx.doi. org/I0.1097/BOR.0b0I3e32834la229

14 Geyer JT, Deshpande V. IgG4-associated sialadenitis. Curr Opin Rheumatol 20II; 23:95-I0I. http://dx.doi.org/I0.1097/ BOR.0b0I3e32834I30II

15 Zen Y, Nakanuma Y. Pathogenesis of IgG4-related disease. Curr Opin Rheumatol 20II; 23:Il4-8. http://dx.doi.org/I0.1097/ BOR.0b0I3e32834I2f4a

16 Carruthers MN, Stone JH, Khosroshahi A. The latest on IgG4-RD: a rapidly emerging disease. Curr Opin Rheumatol 2012; 24:60-9. http://dx.doi.org/I0.1097/BOR.0b013e32834ddb4a

17 Stone JH, Khosroshahi A, Deshpande V et al. Recommendations for the nomenclature of IgG4-related disease and its individual organ system manifestations. Arthritis Rheum 2012; 64:306I-7. http://dx.doi.org//0.1002/art.34593 inconsistencies in immunological testing in our own cases, and believe that this highlights the need for a more uniform diagnostic approach across specialties. We hope this report will help to raise awareness of an underrecognised, serious but treatable condition.

I8 Hamano H, Kawa S, HoriuchiA et al. High serum lgG4 concentrations in patients with sclerosing pancreatitis. New Engl J Med 200I; 344:732-8. http://dx.doi.org/I0.1056/NEJM20010308344I005

19 Chen RY, Adams DB. IgG4 levels in non-Japanese patients with autoimmune sclerosing pancreatitis. New Engl J Med 2002; 346:1919. http://dx.doi.org//0.1056/NEJM200206/33462420

20 Hughes DB, Grobmyer SR, Brennan MF. Preventing pancreaticoduodenectomy for lymphoplasmacytic sclerosing pancreatitis: cost effectiveness of IgG4. Pancreas 2004; 29:167. http://dx.doi.org/10.1097/00006676-200408000-00013

21 Kawano M, Saeki T, Nakashima $\mathrm{H}$ et al. Proposal for diagnostic criteria for IgG4-related kidney disease. Clin Exp Nephrol 201 I; 15:6 I5-26. http://dx.doi.org/I0.1007/s I0157-0 I I-052I-2

22 Umehara $\mathrm{H}$, Okazaki K, Masaki $\mathrm{Y}$ et al. A novel clinical entity, IgG4related disease (IgG4RD): general concept and details. Mod Rheumatol 201 ; 22:1-14. http://dx.doi.org/I0.1007/s I0165-0II-0508-6

23 Neild GH, Rodriguez-Justo M, Wall C et al. Hyper-lgG4 disease: report and characterisation of a new disease. BMC Med 2006; 4:23. http://dx.doi.org/I0.I I86/I74I-70I5-4-23

24 Cravedi P,Abbate M, Gagliardini E et al. Membranous nephropathy associated with IgG4-related disease. Am J Kidney Dis 201I; 58:272-5. http://dx.doi.org/I0.1053/j.ajkd.20II.05.002

25 Van Moerkercke W, Verhamme M, Meeus G et al. A case of IgG4related sclerosing disease with retroperitoneal fibrosis, autoimmune pancreatitis and bilateral focal nephritis. Pancreas 2009; 38:825-32. http://dx.doi.org/10.1097/MPA.0b013e3 I8ac5221

26 Dhobale S, Bedetti C, Killian P et al. IgG4 related sclerosing disease with multiple organ involvements and response to corticosteroid treatment. J Clin Rheumatol 2009; 15:354-7. http://dx.doi. org/I0.1097/RHU.0b013e318Ib5d63I

27 Cornell LD, Chicano SL, Deshpande V et al. Pseudotumors due to lgG4 immune-complex tubulointerstitial nephritis associated with autoimmune pancreatocentric disease. Am J Surg Pathol 2007; 3I:I586-97. http://dx.doi.org/I0.1097/PAS.0b0I3e3I8059b87c

$28 \mathrm{Kim} \mathrm{KP}$, Kim MH, Song $\mathrm{MH}$ et al. Autoimmune chronic pancreatitis. Am J Gastroenterol 2004; 99:1605-16. http://dx.doi. org/I0.I I I I/j.I572-024I.2004.30336.x

29 Pearson RK, Longnecker DS, Chari ST et al. Controversies in clinical pancreatology: autoimmune pancreatitis: does it exist? Pancreas 2003; 27:1-13. http://dx.doi.org//0.1097/00006676200307000-0000I

30 Nishimori I, Tamakoshi A, Otsuki M. Prevalence of autoimmune pancreatitis in Japan from a nationwide survey in 2002.J Gastroenterol 2007; 42 Suppl 18:6-8. http://dx.doi.org/I0.1007/s00535-007-2043-y

31 World Health Organization. GLOBOCAN 2008. Cancer incidence and mortality worldwide. [Internet] France: International Agency for Research on Cancer; 2010 [cited 2013 Jan 24]. Available from: http://globocan.iarc.fr.

32 Simms RW, Prout MN, Cohen AS. The epidemiology of AL and AA amyloidosis. Baillieres Clin Rheumatol 1994; 8:627-34. http://dx.doi. org/10.1016/S0950-3579(05)80119-0

33 Stone JH, Khosroshahi A, DeshpandeV et al. IgG4-related systemic disease accounts for a significant proportion of thoracic lymphoplasmacytic aortitis cases. Arthritis Care Res (Hoboken) 2010; 62:316-22. http://dx.doi.org/I0.1002/acr.20095 
34 Dahlgren M, Khosroshahi A, Nielsen GP, et al. Riedel's thyroiditis and multifocal fibrosclerosis are part of the lgG4-related systemic disease spectrum. Arthritis Care Res (Hoboken) 2010; 62:1312-8. http://dx.doi.org//0.1002/acr.20215

35 Zen $Y$, Onodera $M$, Inoue $D$ et al. Retroperitoneal fibrosis: clinicopathologic study with respect to immunoglobulin G4. Am J Surg Pathol 2009; 33:I833-9. http://dx.doi.org/I0.1097/ PAS.0b0I3e318Ib72882

36 Stone JH, Khosroshahi A, Hilgenberg A et al. IgG4-related systemic disease and lymphoplasmacytic aortitis. Arthritis Rheum 2009; 60:3 139-45. http://dx.doi.org//0.1002/art.24798

37 Khosroshahi A, Stone JH. Treatment approaches to lgG4-related systemic disease. Curr Opin Rheumatol 201I; 23:67-7I. http:// dx.doi.org/I0.1097/BOR.0b0 I3e32834la240

38 Kamisawa T, Okazaki K, Kawa $\mathrm{S}$ et al. Japanese consensus guidelines for management of autoimmune pancreatitis: III. Treatment and prognosis of AIP. J Gastroenterol 2010; 45:47I-7. http://dx.doi.org/I0.1007/s00535-010-022I-9

39 Umehara H, Okazaki K, Masaki Y et al. A novel clinical entity, IgG4related disease (IgG4RD): general concept and details. Mod Rheumatol 2012; 22:I-I4. http://dx.doi.org/I0.1007/s I0I65-0 I I-0508-6

40 Cornell LD. IgG4-related tubulointerstitial nephritis. Kidney Int 20I0; 78:95I-3. http://dx.doi.org//0.1038/ki.20l0.342

4I Yoneda K, Murata K, Katayama K et al.Tubulointerstitial nephritis associated with IgG4-related autoimmune disease. Am J Kid Dis 2007; 50:455-62. http://dx.doi.org/l 0.I053/j.ajkd.2007.05.0I8

42 Saeki T, Nishi S, Ito T et al. Renal lesions in IgG4-related systemic disease. Intern Med 2007; 46:I365-7I. http://dx.doi.org/I0.2169/ internalmedicine.46.0183
43 Nakamura $\mathrm{H}$, Wada $\mathrm{H}$, Origuchi $\mathrm{T}$ et al. A case of IgG4-related autoimmune disease with multiple organ involvement. Scand J Rheumatol 2006; 35:69-7I. http://dx.doi.org//0.1080/03009740500499484

44 Naitoh I, Nakazawa T, Ohara $\mathrm{H}$ et al. Autoimmune pancreatitis associated with various extrapancreatic lesions during a long-term clinical course successfully treated with azathioprine and corticosteroid maintenance therapy. Intern Med 2009; 48:2003-7. http://dx.doi.org//0.2169/internalmedicine.48.2695

45 Mannion M, Cron RQ. Successful treatment of pediatric lgG4 related systemic disease with mycophenolate mofetil: case report and a review of the pediatric autoimmune pancreatitis literature. Pediatr Rheumatol Online J 20 I I; 9: I. http://dx.doi.org//0.I I86/I546-0096-9- I

46 Khan ML, Colby TV,Viggiano RW et al.Treatment with bortezomib of a patient having hyper IgG4 disease. Clin Lymphoma Myeloma Leuk 20I0; I0:2 I7-9. http://dx.doi.org/I0.38I6/CLML.20I0.n.034

47 Khosroshahi A, Carruthers MN, Deshpande V et al. Rituximab for the treatment of IgG4-related disease: lessons from 10 consecutive patients. Medicine (Baltimore) 20I2; 91:57-66. http://dx.doi. org/I0.1097/MD.0b0I3e318243 I ef6

48 Massachusetts General Hospital. Rheumatology Research Laboratory [Internet]. Boston: MGH [cited 2013 Jan 24].Available from: http:// www.massgeneral.org/rheumatology/research/researchlab. aspx?id=|430.

\section{SENIOR FELLOWS' CLUB PRIZE}

The Senior Fellow's Club Prize for 2012 has been won by GEWalker and colleagues for their paper on 'Intravenous fluid use in the acutely unwell adult medical inpatient: improving practice through a clinical audit process'. This can be read in issue 32012 at http://www.rcpe.ac.uk/journal/issue/journal_42_3/wood.pdf

A prize of $£ 250$ will be awarded to the first-named (or corresponding) author of an original research paper on a clinical topic, deemed by a panel of judges to be the best paper by a doctor-in-training (i.e. pre-consultant level) published in The Journal of the Royal College of Physicians of Edinburgh in 2013. The best paper will be selected by a panel of judges, including a senior Fellow, an active clinician and a member of the editorial team.

Further details may be obtained from the Editorial Office, RCPE, 9 Queen Street, Edinburgh, EH2 IJQ, tel 0I3I 2473652 or email editorial@rcpe.ac.uk. 